\title{
Estrogens and male reproduction: a new concept
}

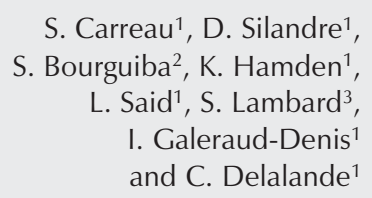

S. Carreau ${ }^{1}$, D. Silandre ${ }^{1}$, S. Bourguiba ${ }^{2}$, K. Hamden ${ }^{1}$, L. Said ${ }^{1}$, S. Lambard ${ }^{3}$, I. Galeraud-Denis ${ }^{1}$ and C. Delalande ${ }^{1}$

\author{
'Department of Biochemistry, University of Caen, Caen, France \\ 2Physiology Department, Turku University, Turku, Finland \\ ${ }^{3}$ Centre Hospitalier Universitaire St. Antoine, Paris, France
}

\author{
Correspondence \\ S. Carreau \\ EA 2608-USC 2006 INRA \\ Université de Caen \\ Esplanade de la paix, 14032 \\ Caen \\ France \\ Fax: +33-231-565-120 \\ E-mail: serge.carreau@unicaen.fr \\ Research supported by the French \\ Ministry of Education and Research, \\ National Institute of Research in \\ Agronomy and Région Basse- \\ Normandie.
}

Received January 3, 2007

Accepted May 4, 2007

.................

\begin{abstract}
The mammalian testis serves two main functions: production of spermatozoa and synthesis of steroids; among them estrogens are the end products obtained from the irreversible transformation of androgens by a microsomal enzymatic complex named aromatase. The aromatase is encoded by a single gene (cyp19) in humans which contains 18 exons, 9 of them being translated. In rats, the aromatase activity is mainly located in Sertoli cells of immature rats and then in Leydig cells of adult rats. We have demonstrated that germ cells represent an important source of estrogens: the amount of P450arom transcript is 3-fold higher in pachytene spermatocytes compared to gonocytes or round spermatids; conversely, aromatase activity is more intense in haploid cells. Male germ cells of mice, bank voles, bears, and monkeys express aromatase. In humans, we have shown the presence of a biologically active aromatase and of estrogen receptors $(\alpha$ and $\beta)$ in ejaculated spermatozoa and in immature germ cells in addition to Leydig cells. Moreover, we have demonstrated that the amount of P450arom transcripts is $30 \%$ lower in immotile than in motile spermatozoa. Alterations of spermatogenesis in terms of number and motility of spermatozoa have been described in men genetically deficient in aromatase. These last observations, together with our data showing a significant decrease of aromatase in immotile spermatozoa, suggest that aromatase could be involved in the acquisition of sperm motility. Thus, taking into account the widespread localization of aromatase and estrogen receptors in testicular cells, it is obvious that, besides gonadotrophins and androgens, estrogens produced locally should be considered to be physiologically relevant hormones involved in the regulation of spermatogenesis and spermiogenesis.
\end{abstract}

Key words

- Aromatase

- Estrogens

- Estrogen receptors

- Male germ cells

- Fertility

- Mammals

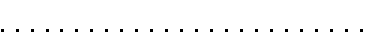

\section{Introduction}

It is well known that normal testicular development and the maintenance of spermatogenesis are controlled by gonadotrophins and testosterone whose effects are modulated by a complex network of locally produced factors, with estrogens being obviously involved. Estrogens have long been considered to be specific female hormones; however, the presence of estrogens in the male gonad has been well documented since the publication of Zondek (1) more than 70 years ago showing the presence of estrogen 
Figure 1. Schematic presentation of the human aromatase gene. $\mathrm{P}=$ promoter. in stallion urine (for a review, see Ref. 2). Indeed the androgen/estrogen balance is essential for normal sexual development and reproduction in mammals. In the mammalian testis, the maintenance of this balance is under a fine tuning via endocrine and paracrine factors, but is also related to aromatase activity. Aromatase, an enzymatic complex, ensures androgen conversion to estrogens and is localized in the endoplasmic reticulum of various tissues including placenta, gonads, brain, bones, and adipose tissue.

Besides the well-known negative effect exerted by these female hormones on the secretion of gonadotrophins, estrogens play a major role in situ and appear to be important not only in women but also in men, especially taking into account the data obtained from men genetically deficient in aromatase (for a review, see Ref. 3). Moreover, in several epidemiological studies decreased sperm counts and increased male reproductive tract disorders (cryptorchidism, hypospadia, testicular cancer) have been attributed to a deleterious effect of endocrine disruptors with either estrogenic or antiandrogenic actions $(4,5)$. Therefore, the capac- ity of the testis to synthesize estrogens has been extensively studied. Over the last two decades the role of estrogens in male reproduction has been seriously revisited especially in primates taking into account the existence of specific estrogen receptors (ER $\alpha$ and ER 3 ) which are distributed all along the genital tract (for reviews, see Refs. 2,6-9).

\section{Presence of aromatase in testicular cells of mammals and humans}

The aromatase gene

Aromatase is composed of two proteins: a ubiquitous NADPH-cytochrome P450 reductase and a cytochrome $\mathrm{P} 450$ aromatase (P450arom), which contains the heme and the steroid-binding pocket. In humans, P450arom is the product of a single gene located in region q21.1 of chromosome 15 and called cyp19, which belongs to the cytochrome P450 gene family. The cyp19 gene is more than $123 \mathrm{~kb}$ in length with a coding region of 9 exons (II-X) and 9 nontranslated exons I (Figure 1). Expression of the cyp19 gene is regulated by tissue-specific promot-

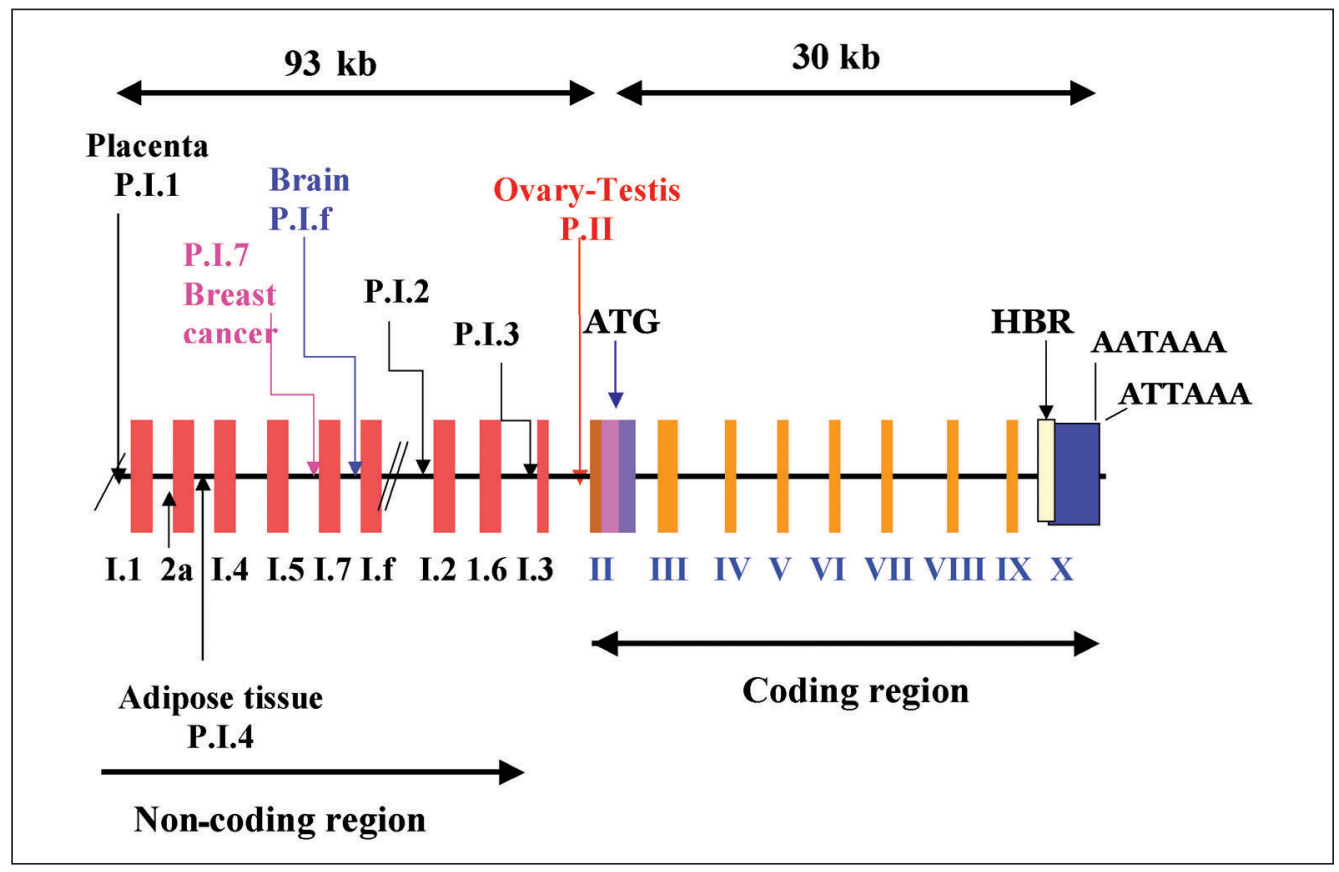


ers producing alternate 5'-untranslated exons I that are then spliced onto a common 3'splice acceptor site in exon II, upstream of the translation starting site (for reviews, see Refs. 10-12). Therefore, there is generation of cyp19 variants with different 5'untranslated regions giving rise to different mRNAs; however, the coding sequences are identical and give rise in humans to a single protein composed of 503 amino acids with a molecular mass of $55 \mathrm{kDa}$. It is of note that P450arom is encoded by a single cyp 19 gene in most species except for pigs in which three distinct genes encode three aromatase isoenzymes (13) and for fish in which two cyp19 genes (specifically expressed in the brain and gonads) have been identified (14).

\section{Presence of a biologically active aromatase in male germ cells}

As abundantly documented in the literature, it is difficult to find a tissue completely devoid of aromatase gene expression (10). Despite the large number of experiments carried out both in vitro and in vivo in different strains of various species, an agreement on the precise localization of aromatase activity at different ages has not always been evident. Indeed, studies investigating the testicular site of androgen aromatization in rat testicular tissues and/or in isolated cells have shown that Leydig cells express aromatase. In the rat there is an age-related change in the cellular distribution of aromatase activity, which is mainly found in Sertoli cells in immature animals and in Leydig cells in adults $(7,9)$. Nevertheless, for the first time in 1993, Nitta et al. (15) reported the presence of aromatase in male germ cells of the mouse. During the same period, with the tools to check the expression of the aromatase gene being available in our laboratory, we decided to carefully re-examine the source of estrogens in adult rat testicular cells. As a matter of fact, we demonstrated an additional source of estrogens in purified pachy- tene spermatocytes (PS), round spermatids (RS) and spermatozoa of adult rats $(16,17)$, in agreement with the data of Janulis et al. (18) showing a stronger immunostaining for aromatase in elongated spermatids. The amount of P450arom mRNA decreases according to the stage of germ cell maturation, being higher in younger than in mature rat germ cells. Conversely, aromatase activity is higher in spermatozoa than in PS or RS. Even if adult Sertoli cells may express aromatase (16), it is well known that germ cells exert a negative control on P450arom gene expression (19), leading to the conclusion that roughly half the testicular aromatase activity is located in germ cells $(20,21)$. We have recently extended our studies, showing that preleptotene spermatocytes and spermatogonia contain aromatase, whereas peritubular cells are devoid of P450arom (Figure 2). Thus, we demonstrated that aromatase is constitutively expressed in all testicular cells except myoid cells in the rat (9; Silandre D, Delalande C, Carreau S, unpublished results). It is noteworthy that the epididymal cells of the rat also contain aromatase (22). Similarly, aromatase has been demonstrated in the germ cells of the bank vole, and its expression is photoperiod-dependent, i.e.,

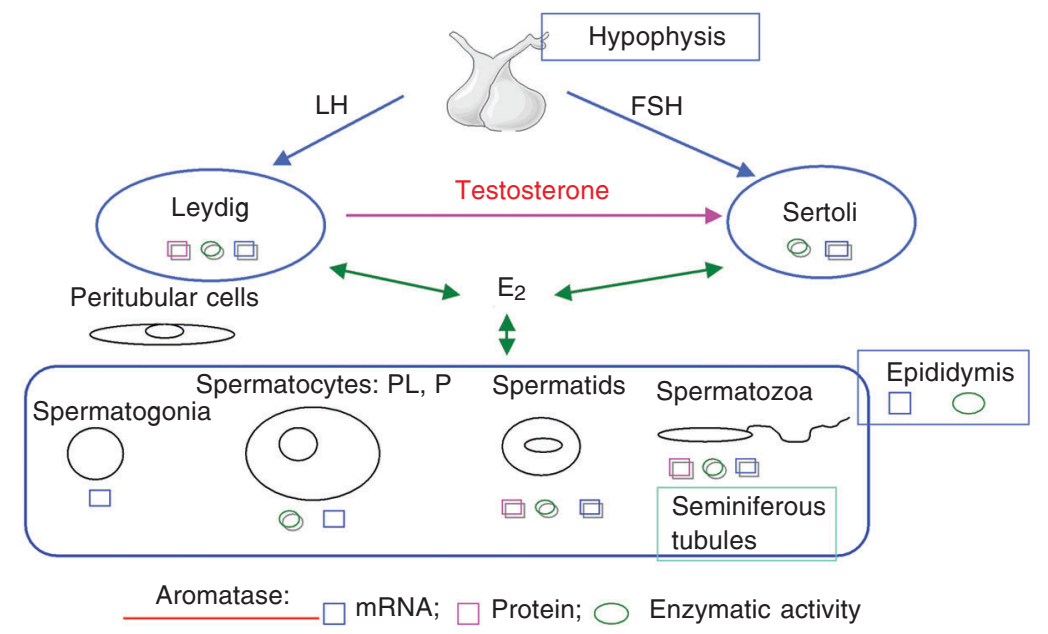

Figure 2. Localization of aromatase in adult rat testicular cells. $\mathrm{PL}=$ preleptotene; $\mathrm{P}=$ pachytene; $\mathrm{E}_{2}=$ estradiol. 
much more intense under long-light cycle conditions which coincide with the breeding season (23). Identical data have been reported for the bear (24).

In the stallion, many estrogens are synthesized by Leydig cells (for a review, see Ref. 25). In contrast to the data of Hess and Roser (26), Hejmej et al. (27) have recently immunohistolocalized aromatase not only in Leydig cells, but also to epididymal cells and to the germ cells present in the lumen of the epididymis. In the boar testis the main source of estrogens is in the Leydig cells (28).

\section{Aromatase in primate testes}

In humans, Leydig cells have long been considered to be the only source of estrogens (29); however, in vitro both Leydig cells and Sertoli cells produce estrogens (for a review, see Ref. 30). It has also been claimed that spermatozoa can convert pregnenolone into estrogens (31). After obtaining data on the expression of aromatase in male germ cells of the rat, we decided to check for the presence of aromatase in ejaculated spermatozoa from healthy donors. In a second approach, we hypothesized that aromatase could be used as a marker of sperm quality (especially motility) and thus we measured the amount of P450arom transcripts in motile and immotile spermatozoa. In addition, since no information was available on the source of estrogens in testicular germ cells, we examined by RT-PCR the putative expression of cyp19 in immature germ cells (spermatocytes and spermatids) obtained from semen samples with large number of round cells (32). Briefly, the quality of the germ cell preparations was carefully analyzed in order to eliminate any sample contamination with leukocytes via the expression of CD45 transcript and with Sertoli cells via the presence of the Sertoli cell factor mRNA. All samples containing detectable levels of these transcripts were eliminated; conversely the presence of $c$-kit mRNA in round cells was used as a positive control for the presence of germ cells. We detected the presence of P450arom transcripts in both immature germ cells and ejaculated spermatozoa. The sequence analysis of the PCR products obtained was identical and showed more than $98 \%$ identity to the published sequence of human P450arom (33). Using Western blots and a specific monoclonal antibody against a highly conserved region of aromatase we demonstrated the presence of aromatase in both immature germ cells and ejaculated sperm cells, with the staining intensity being more abundant in spermatozoa containing cytoplasmic droplets.

Moreover, we demonstrated that the amount of P450arom transcripts was 30\% lower in immotile than in motile spermatozoa from several samples individually prepared by density gradient purification; in addition, the aromatase activity was 50\% greater in the motile fraction compared to immotile spermatozoa. Our observations showing that aromatase was expressed both as a transcript and as a biologically active protein in spermatozoa from normal donors agree with other data (34). These latter observations are correlated with the immunolocalization of aromatase in cytoplasm surrounding elongated spermatids in man (35) and aromatase has also been revealed in cytoplasmic droplets of ejaculated human spermatozoa (36). Recently, Carpino et al. (37) have immunolocalized aromatase in the epithelial cells of human efferent ducts and to the proximal caput epididymis, suggesting an additional source of estrogens in the male genital tract. Similar observations have been made on rhesus monkeys, whose testis and, to a lesser extent, epididymis contained two P450arom transcripts, one of them being truncated (38).

\section{Regulation of aromatase gene expression}

In order to obtain insights about the role of estrogens in male reproduction and espe- 
cially within seminiferous tubules, it is necessary to study the regulation of the cyp 19 gene (for a review, see Ref. 39). Thus, using RACE-PCR we demonstrated that promoter II directs the expression of the aromatase gene whatever the testicular cell type studied in the rat (40). In the testis, folliclestimulating hormone and luteinizing hormone both act to increase the concentrations of intracellular cyclic AMP (cAMP), thereby inducing expression of P450arom which in turn requires the transcription factors cAMP response element-binding protein, cAMP response element modulator and steroidogenic factor-1 (SF-1). SF-1 belongs to the nuclear orphan receptor superfamily and regulates the transcription of steroidogenic genes, among them P450arom via its interaction with numerous co-activators such as cAMP response element-binding protein, DAX-1, SOX-9, and WT1. In addition, we have shown that liver receptor homologue1, an SF-1 homologue, which is present both in Leydig cells and germ cells, but not in Sertoli cells, increases the P450arom gene expression in a mouse Leydig cell line (41). Numerous functional motifs have been identified in P.II (11); in this context it is worth noting that truncated transcripts of the $\mathrm{P} 450$ arom gene giving rise to putative inactive proteins have been described in PS and RS of adult rats (42). Moreover, it is now clear that not only P.II drives the aromatase gene in rat testis but two additional promoters, P.I.f (brain promoter) and a new one that we called P.I.Tr (testis rat; Silandre D, Delalande $\mathrm{C}$, Carreau $\mathrm{S}$, unpublished results), are involved. We have also demonstrated that the nutritional status of fetuses (43) and aging (Hamden K, Silandre D, Delalande C, El Feki A, Carreau S, unpublished results) can modulate aromatase gene expression in male rats. In mice it has been shown that aromatase expression is controlled by three different promoters, among them a testis-specific promoter (44). In human gonads, only the P.II promoter has been reported to control aromatase gene expression thus far (45).

\section{Estrogen receptors in the male genital tract}

In order to exert a biological role, testicular estrogens should interact with ERs, which in turn modulate the transcription of specific genes. Until 1996, the only data on ERs concerned ER $\alpha$; however, with the discovery of a novel ER denoted ERß, the localization of ERs has been reexamined, and it has been shown that the $\alpha$ and $\beta$ forms are not always present in the same cells (or are present in different amounts) within the male genital tract. The distribution of the mRNAs coding for the two types of ERs in the male rat gonad has been studied (46) and Saunders et al. (47) have shown the presence of ER $\beta$ in pachytene spermatocytes and spermatids. ERß has also been immunolocalized in Leydig cells and in the seminiferous tubules of the bank vole (23).

Mutembei et al. (48) have shown that ERß is ubiquitously distributed in the testicular cells of the boar including Leydig cells and is absent only in elongated spermatids. Conversely ER $\alpha$ is very weakly expressed in Leydig cells and is much more abundant in young germ cells (spermatogonia and PS). Therefore, species differences are obvious and the pig seems to have a unique distribution of ERs consitent with the large amounts of estrogen produced in boar testes (for a review, see Ref. 25).

In immature germ cells of men we have identified both in terms of transcripts and proteins the two main isoforms of ERs, not only the full-length one but also some variants (32). Besides the wild type of ER $\alpha$, an additional transcript related to the exon1deleted variant of ER $\alpha$ with a $46-\mathrm{kDa}$ molecular mass has been reported in ejaculated sperm. Concerning ERß, two isoforms (in terms of transcript and protein) corresponding to the expected sizes (full-length and 
shorter one) were detected in germ cells, whereas in spermatozoa only the PCR product was found (49). Aquila et al. (50) have described the presence of ER $\alpha$ and ERß in human ejaculated spermatozoa both as transcripts and as proteins corresponding to the well-characterized ER forms. These discrepancies with our studies could be due to the different methodologies used. Recently, Aschim et al. (51) reported the presence of several splice variants of ERß in human testicular cells but the proteins have not been yet identified and thus their specific functions remain to be elucidated. Solakidi et al. (52) have also demonstrated by confocal analysis the presence of the two main ERs in ejaculated sperm. In primates, both ERs have been demonstrated but it is clear that Leydig cells mainly express ER $\alpha$ whereas in seminiferous tubules ER $\beta$ and $E R \alpha$ are present especially in PS and RS (for a review, see Ref. 53).

Thus, a general statement can be made: $\mathrm{ER} \alpha$ is mainly localized in Leydig cells whereas ERß is found in the seminiferous tubules and mainly in germ cells.

\section{Conclusions: estrogens and male fertility}

In conclusion, the net biological effect of estrogen in the testis was long thought to be mainly negative. In view of the widespread distribution of ERs in male gonads and an additional expression of aromatase in germ cells, the role of estrogens in male reproduction is more complex than previously realized. Regarding the role of estrogens in male gamete maturation, we have shown not only the existence of estrogen sources in various germ cells but also the presence of ER $\alpha$ and
$E R ß$ and, in addition, the presence of a truncated form of ER $\alpha$ (probably localized on the membrane) in ejaculated human sperm. Indeed, the motility and number of spermatozoa are reduced in diminished aromatasedeficient men (for a review, see Ref. 3). In general, an impairment of fertility is observed in men with a defect of the aromatase gene. These observations of decreased sperm motility in men with aromatase deficiency, together with our data showing a significant decrease of aromatase in immotile human spermatozoa, could suggest that aromatase is involved in the acquisition of sperm motility. In mouse as well as in man it has been shown that estrogens are positively involved in sperm capacitation and acrosome reaction (54). The existence of ERs on the sperm membrane (55) and in the mitochondria (52) is likely to be relevant for a role of estrogens in male gamete motility.

Consequently, the production of estrogens by germ cells and the existence of ERs represent good markers which should help to understand the physiological role of estrogens in human spermatogenesis. As also suggested by Ostermeier et al. (56), the genetic fingerprint of fertile men could include the analysis of mRNA profiles and thus aromatase and ERs may be helpful. Nevertheless, it is clear that further studies are necessary to elucidate the real impact of estrogen on human male reproduction, although it is obvious that several steps are involved (54). Even if numerous estrogentargeted genes remain to be defined, there is now a body of evidence in favor of a positive role for estrogens in male reproduction via genomic and rapid membrane effects (for a review, see Ref. 57). 


\section{References}

1. Zondek B. Mass excretion of oestrogenic hormone in the urine of the stallion. Nature 1934; 193: 209-210.

2. Carreau S, Genissel C, Bilinska B, Levallet J. Sources of oestrogen in the testis and reproductive tract of the male. Int J Androl 1999; 22: 211-223.

3. Rochira V, Granata AR, Madeo B, Zirilli L, Rossi G, Carani C. Estrogens in males: what have we learned in the last 10 years? Asian J Androl 2005; 7: 3-20.

4. Toppari J, Larsen JC, Christiansen P, Giwercman A, Grandjean P, Guillette LJ Jr, et al. Male reproductive health and environmental xenoestrogens. Environ Health Perspect 1996; 104 (Suppl 4): 741803.

5. Skakkebaek NE. Testicular dysgenesis syndrome: new epidemiological evidence. Int J Androl 2004; 27: 189-191.

6. Hess RA. Estrogen in the adult male reproductive tract: a review. Reprod Biol Endocrinol 2003; 1: 52.

7. Carreau S, Lambard S, Delalande C, Denis-Galeraud I, Bilinska B, Bourguiba S. Aromatase expression and role of estrogens in male gonad: a review. Reprod Biol Endocrinol 2003; 1: 35.

8. O'Donnell L, Robertson KM, Jones ME, Simpson ER. Estrogen and spermatogenesis. Endocr Rev 2001; 22: 289-318.

9. Carreau S, Delalande C, Silandre D, Bourguiba S, Lambard S. Aromatase and estrogen receptors in male reproduction. Mol Cell Endocrinol 2006; 246: 65-68.

10. Simpson ER, Mahendroo MS, Means GD, Kilgore MW, Hinshelwood MM, Graham-Lorence S, et al. Aromatase cytochrome P450, the enzyme responsible for estrogen biosynthesis. Endocr Rev 1994; 15: 342-355.

11. Simpson ER, Clyne C, Rubin G, Boon WC, Robertson K, Britt K, et al. Aromatase - a brief overview. Annu Rev Physiol 2002; 64: 93127.

12. Sebastian S, Bulun SE. A highly complex organization of the regulatory region of the human CYP19 (aromatase) gene revealed by the Human Genome Project. J Clin Endocrinol Metab 2001; 86: 46004602.

13. Graddy LG, Kowalski AA, Simmen FA, Davis SL, Baumgartner WW, Simmen RC. Multiple isoforms of porcine aromatase are encoded by three distinct genes. J Steroid Biochem Mol Biol 2000; 73: 49-57.

14. Kishida M, Callard GV. Distinct cytochrome P450 aromatase isoforms in zebrafish (Danio rerio) brain and ovary are differentially programmed and estrogen regulated during early development. Endocrinology 2001; 142: 740-750.

15. Nitta H, Bunick D, Hess RA, Janulis L, Newton SC, Millette CF, et al. Germ cells of the mouse testis express P450 aromatase. Endocrinology 1993; 132: 1396-1401.

16. Levallet J, Carreau S. In vitro gene expression of aromatase in rat testicular cells. C R Acad Sci III 1997; 320: 123-129.

17. Bourguiba S, Chater S, Delalande C, Benahmed M, Carreau S. Regulation of aromatase gene expression in purified germ cells of adult male rats: effects of transforming growth factor beta, tumor necrosis factor alpha, and cyclic adenosine 3',5'-monosphosphate. Biol Reprod 2003; 69: 592-601.

18. Janulis L, Bahr JM, Hess RA, Bunick D. P450 aromatase messenger ribonucleic acid expression in male rat germ cells: detection by reverse transcription-polymerase chain reaction amplification. $J$ Androl 1996; 17: 651-658.

19. Boitani C, Ritzen EM, Parvinen M. Inhibition of rat Sertoli cell aromatase by factor(s) secreted specifically at spermatogenic stages VII and VIII. Mol Cell Endocrinol 1981; 23: 11-22.

20. Carreau S, Bourguiba S, Lambard S, Galeraud-Denis I, Genissel C, Levallet J. Reproductive system: aromatase and estrogens. Mol Cell Endocrinol 2002; 193: 137-143.

21. Lambard S, Silandre D, Delalande C, Denis-Galeraud I, Bourguiba $\mathrm{S}$, Carreau S. Aromatase in testis: expression and role in male reproduction. J Steroid Biochem Mol Biol 2005; 95: 63-69.

22. Wiszniewska $B$. Primary culture of the rat epididymal epithelial cells as a source of oestrogen. Andrologia 2002; 34: 180-187.

23. Bilinska B, Schmalz-Fraczek B, Kotula M, Carreau S. Photoperioddependent capability of androgen aromatization and the role of estrogens in the bank vole testis visualized by means of immunohistochemistry. Mol Cell Endocrinol 2001; 178: 189-198.

24. Tsubota T, Howell-Skalla L, Nitta H, Osawa Y, Mason JI, Meiers PG, et al. Seasonal changes in spermatogenesis and testicular steroidogenesis in the male black bear Ursus americanus. J Reprod Fertil 1997; 109: 21-27.

25. Carreau S. Leydig cell aromatase: from gene to physiology. In: Payne AH, Hardy MP (Editors), The Leydig cell in health and disease. Totowa: Humana Press; 2007 (in press).

26. Hess MF, Roser JF. Immunocytochemical localization of cytochrome P450 aromatase in the testis of prepubertal, pubertal, and postpubertal horses. Theriogenology 2004; 61: 293-299.

27. Hejmej A, Gorazd M, Kosiniak-Kamysz K, Wiszniewska B, Sadowska J, Bilinska B. Expression of aromatase and oestrogen receptors in reproductive tissues of the stallion and a single cryptorchid visualised by means of immunohistochemistry. Domest Anim Endocrinol 2005; 29: 534-547.

28. Weng Q, Medan MS, Watanabe G, Tsubota T, Tanioka Y, Taya K. Immunolocalization of steroidogenic enzymes P450scc, 3betaHSD, P450c17, and P450arom in Göttingen miniature pig testes. J Reprod Dev 2005; 51: 299-304.

29. Payne AH, Kelch RP, Musich SS, Halpern ME. Intratesticular site of aromatization in the human. J Clin Endocrinol Metab 1976; 42: 1081-1087.

30. Carreau S. Paracrine control of human Leydig cell and Sertoli cell functions. Folia Histochem Cytobiol 1996; 34: 111-119.

31. Gunasegaram R, Chew PC, Loganath A, Peh KL, Ratnam SS. A delta 4-3-keto pathway for testosterone synthesis in the human spermatozoa. Arch Androl 1998; 40: 49-57.

32. Lambard S, Galeraud-Denis I, Saunders PTK, Carreau S. Human immature germ cells and ejaculated spermatozoa contain aromatase and oestrogen receptors. J Molec Endocrinol 2004; 32: 289.

33. Lambard S, Galeraud-Denis I, Bouraïma H, Bourguiba S, Chocat A, Carreau S. Expression of aromatase in human ejaculated spermatozoa: a putative marker of motility. Molec Human Reprod 2003; 9: 117-124.

34. Aquila S, Sisci D, Gentile M, Middea E, Siciliano L, Ando S. Human ejaculated spermatozoa contain active P450 aromatase. J Clin Endocrinol Metab 2002; 87: 3385-3390.

35. Turner KJ, MacPherson S, Millar MR, McNeilly AS, Williams K, Cranfield M, et al. Development and validation of a new monoclonal antibody to mammalian aromatase. J Endocrinol 2002; 172: 21-30.

36. Rago V, Bilinska B, Palma A, Ando S, Carpino A. Evidence of aromatase localization in cytoplasmic droplets of human immature ejaculated spermatozoa. Folia Histochem Cytobiol 2003; 41: 23-27.

37. Carpino A, Romeo F, Rago V. Aromatase immunolocalization in human ductuli efferentes and proximal ductus epididymis. J Anat 
2004; 204: 217-220.

38. Pereyra-Martinez AC, Roselli CE, Stadelman HL, Resko JA. Cytochrome P450 aromatase in testis and epididymis of male rhesus monkeys. Endocrine 2001; 16: 15-19.

39. Carreau S, Bourguiba S, Lambard S, Silandre D, Delalande C. The promoter(s) of the aromatase gene in male testicular cells. Reprod Biol 2004; 4: 23-34.

40. Lanzino M, Catalano S, Genissel C, Ando S, Carreau S, Hamra K, et al. Aromatase messenger RNA is derived from the proximal promoter of the aromatase gene in Leydig, Sertoli, and germ cells of the rat testis. Biol Reprod 2001; 64: 1439-1443.

41. Pezzi V, Sirianni R, Chimento A, Maggiolini M, Bourguiba S, Delalande $C$, et al. Differential expression of steroidogenic factor-1/ adrenal 4 binding protein and liver receptor homolog-1 ( $\mathrm{LRH}-1)$ / fetoprotein transcription factor in the rat testis: $\mathrm{LRH}-1$ as a potential regulator of testicular aromatase expression. Endocrinology 2004; 145: 2186-2196.

42. Levallet J, Mittre H, Delarue B, Carreau S. Alternative splicing events in the coding region of the cytochrome $\mathrm{P} 450$ aromatase gene in male rat germ cells. $J$ Mol Endocrinol 1998; 20: 305-312.

43. Teixeira CV, Silandre D, de Souza Santos AM, Delalande C, Sampaio FJ, Carreau S, et al. Effects of maternal undernutrition during lactation on aromatase, estrogen, and androgen receptors expression in rat testis at weaning. $J$ Endocrinol 2007; 192: 301311.

44. Golovine K, Schwerin M, Vanselow J. Three different promoters control expression of the aromatase cytochrome p450 gene (cyp19) in mouse gonads and brain. Biol Reprod 2003; 68: 978-984.

45. Bulun SE, Rosenthal IM, Brodie AM, Inkster SE, Zeller WP, DiGeorge AM, et al. Use of tissue-specific promoters in the regulation of aromatase cytochrome P450 gene expression in human testicular and ovarian sex cord tumors, as well as in normal fetal and adult gonads. J Clin Endocrinol Metab 1993; 77: 1616-1621.

46. Kuiper GG, Carlsson B, Grandien K, Enmark E, Haggblad J, Nilsson $\mathrm{S}$, et al. Comparison of the ligand binding specificity and transcript tissue distribution of estrogen receptors alpha and beta. Endocrinology 1997; 138: 863-870.

47. Saunders PT, Fisher JS, Sharpe RM, Millar MR. Expression of oestrogen receptor beta (ER beta) occurs in multiple cell types, including some germ cells, in the rat testis. J Endocrinol 1998; 156:
R13-R17.

48. Mutembei HM, Pesch S, Schuler G, Hoffmann B. Expression of oestrogen receptors alpha and beta and of aromatase in the testis of immature and mature boars. Reprod Domest Anim 2005; 40: 228236.

49. Lambard S, Carreau S. Aromatase and oestrogens in human male germ cells. Int J Androl 2005; 28: 254-259.

50. Aquila S, Sisci D, Gentile M, Middea E, Catalano S, Carpino A, et al. Estrogen receptor (ER)alpha and ER beta are both expressed in human ejaculated spermatozoa: evidence of their direct interaction with phosphatidylinositol-3-OH kinase/Akt pathway. J Clin Endocrinol Metab 2004; 89: 1443-1451.

51. Aschim EL, Saether T, Wiger R, Grotmol T, Haugen TB. Differential distribution of splice variants of estrogen receptor beta in human testicular cells suggests specific functions in spermatogenesis. $J$ Steroid Biochem Mol Biol 2004; 92: 97-106.

52. Solakidi S, Psarra AM, Nikolaropoulos S, Sekeris CE. Estrogen receptors alpha and beta (ERalpha and ERbeta) and androgen receptor (AR) in human sperm: localization of ERbeta and $A R$ in mitochondria of the midpiece. Hum Reprod 2005; 20: 3481-3487.

53. Saunders PT, Sharpe RM, Williams K, MacPherson S, Urquart $H$, Irvine DS, et al. Differential expression of oestrogen receptor alpha and beta proteins in the testes and male reproductive system of human and non-human primates. Mol Hum Reprod 2001; 7: 227236.

54. Carreau S, Lambard S, Said L, Saad A, Galeraid-Denis I. RNA dynamics of fertile and nonfertile spermatozoa. Biochem Trans Soc 2007 (in press).

55. Luconi M, Francavilla F, Porazzi I, Macerola B, Forti G, Baldi E. Human spermatozoa as a model for studying membrane receptors mediating rapid nongenomic effects of progesterone and estrogens. Steroids 2004; 69: 553-559.

56. Ostermeier GC, Goodrich RJ, Diamond MP, Dix DJ, Krawetz SA Toward using stable spermatozoal RNAs for prognostic assessment of male factor fertility. Fertil Steril 2005; 83: 1687-1694.

57. Carreau S, Bourguiba S, Delalande C, Silandre D, Said L, GaleraudDenis I, et al. Estrogen roles in spermatogenesis. In: CMC-IEMA special issue (Editor), Male contraception - recent advances and future perspectives. 2007 (in press). 